\title{
REVISTA REFLEXÃO E AÇÃO: EM BUSCA DE CONHECIMENTO E QUALIFICAÇÃO
}

\author{
Stéla Piccin ${ }^{1}$ \\ Felipe Gustsack ${ }^{2}$ \\ Ieda de Camargo ${ }^{3}$
}

A Reflexão e Ação é publicação semestral do Departamento de Educação e do Programa de Pós-Graduação em Educação - Mestrado da UNISC (PPGEdu). Seu principal escopo é debater as problemáticas contemporâneas da área educacional, assim como divulgar a produção científica da área e afins. Atualmente a revista é ranqueada B2 no Qualis CAPES.

Desde sua primeira edição, em 1992, até 2006, veiculou versões impressas, passando a ser, a partir de 2007, exclusivamente online. Além de disponibilizar seu conteúdo em um portal de revistas eletrônicas de acesso livre, possui, em sua página na internet, fluxo contínuo de recebimento de artigos, resenhas e relatos de experiência. Suas edições visam a problematizar, através de números temáticos, discussões relevantes para o contexto educacional, procurando abordar e debater diferentes perspectivas que possam contribuir com os debates da comunidade científica, especialmente na área da Educação. O periódico também conta com a colaboração de diversos profissionais da área da educação, incluindo pesquisadores de outros países, como membros do comitê científico e avaliadores ad hoc.

Juntamente como os editores, com o PPGEdu, com o Departamento de Educação e com a equipe técnica da Universidade, de modo geral, a revista está em constante interlocução acerca de projetos para sua qualificação e valorização. Dentre as principais propostas estão o aumento do número de edições, de duas para quatro edições por ano, bem como a disponibilização das edições impressas, veiculadas entre 1992 e 2007, em formato digital. Busca-se qualificar o periódico através de publicações de textos em outras línguas, assim como contar com autores, avaliadores, dentre outros colaboradores nacionais e internacionais. Também há procura na concorrência a editais que visem fomentar os periódicos, a fim de qualificar a revista. Essas e outras tantas propostas visam a melhorar as fontes de indexação e a classificação no ranking Qualis da CAPES.

\footnotetext{
${ }^{1}$ Acadêmica do Curso de Letras da Universidade de Santa Cruz do Sul-UNISC. Departamento de Letras. <stelapiccin@mx2.unisc.br>

2 Professor da Universidade de Santa Cruz do Sul- UNISC. Departamento de Educação. Doutor em Educação. <fegus@unisc.br>

3 Professora da Universidade de Santa Cruz do Sul- UNISC. Departamento de Educação. Doutora em Educação. < ieda@unisc.br>
} 
A atuação na revista proporciona inúmeros aprendizados. A oportunidade de desenvolver atividades em um periódico científico é, sem dúvidas, uma experiência enriquecedora para alunos da graduação em Letras. Além de compreender a sistematização da vinculação da produção científica, a atuação do bolsista possibilita conviver e compartilhar saberes com outros bolsistas, alunos, professores e funcionários do PPGEdu e da UNISC como um todo. A revista publica números temáticos, contando com a colaboração de professores/pesquisadores vinculados à UNISC e a outras universidades. Cabe, então, ao bolsista a organização das edições e a realização das conversações que viabilizam a publicação das edições.

Assim, as atividades na Reflexão e Ação estimulam, cotidianamente, reflexões sobre as diversas discussões acerca da educação e suas problemáticas, nas quais percebemos a importância dos periódicos para divulgação e propagação do conhecimento e de estudos que tratam das mais diversas emergências da área da educação.

\section{REFERÊNCIAS}

REVISTA REFLEXÃO E AÇÃO. Desenvolvida pelo Departamento de Educação e pelo Programa de Mestrado em Educação. 2007-2014. Apresenta Artigos temáticos, Artigos especiais e relatos de experiências na área da educação. Disponível em<http://online.unisc.br/seer/index.php/reflex/index>. Acesso em: 25 de mar. de 2014. 